\title{
Integrating spirituality in the approach to psychiatric practice
}

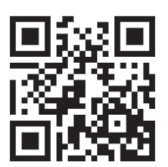

Interest in spirituality and psychiatry has grown significantly over the past two decades. Since the 1990s, interest groups have been formed by several professional associations in the USA, Canada, the UK, the Netherlands, Brazil and Australia. Interest in spirituality, religion and culture has, however, always existed in Africa and has recently in a South African (SA) context also emerged more publicly in secular areas such as health and mental health, where the need to be 'culturally competent' has extended to competence regarding the multireligious and spiritually diverse contexts of local medical practice.

Locally, in SA, a Spirituality and Psychiatry Special Interest Group (S\&PSIG) of the South African Society of Psychiatrists (SASOP) was established with the objectives, among others, to promote, maintain and protect the discipline of psychiatry as a medical speciality as far as it relates to spirituality as an additional dimension to the biopsychosocial model, and to provide a forum to clarify concepts and professional boundaries. It also became important to develop local guidelines, which was initiated by the S\&PSIG, undertaken in view of the extent of local and worldwide religious affiliation, rapid growth of academic investigation, ${ }^{[1]}$ guidelines by other associations (e.g. Royal College of Psychiatrists), ${ }^{[2]}$ and SASOP's own position statement on culture, mental health and psychiatry. ${ }^{[3]}$

\section{South African studies}

In what seemed to have been a changing environment, an explorative qualitative inquiry was undertaken to capture the views and experiences of some local psychiatrists on the role of spirituality in psychiatric practice and training. ${ }^{[4]}$ In addition, Bulbulia and Laher ${ }^{[5]}$ subsequently reported on the role of Islam in perceptions of mental illness in a sample of Muslim psychiatrists in Johannesburg, while Padayachee and Laher ${ }^{[6]}$ reported on SA Hindu psychologists perceptions of mental illness.

\section{Training}

Undergraduate medical curricula in the USA have focused on including the development of skills in the human dimensions of clinical practice, including understanding the meaning of patients' stories in the context of their beliefs and cultural values. ${ }^{[7]}$ As such, the different local faculties of health sciences may also have to consider how to appropriately integrate spirituality in the curricula of undergraduates. ${ }^{[8]}$

Regarding postgraduate training, with the Part II FCPsych (SA) of the South African College of Psychiatrists now the only exit examination, the curriculum has been reviewed and subjected to extensive blueprinting. Consensus is still needed, though, on the knowledge and skills required to assess candidates' cultural competence to practise in a local context.

\section{Practice}

As indicated by the mentioned SASOP guidelines, possible activities in this regard may include more structured communication between representatives of psychiatrists and religious or spiritual advisors, exploring referral arrangements in a geographical catchment area context at facility or district level, and establishing forums for mental health education. ${ }^{[9]}$

\section{Research}

Research on culture, religion, spirituality and psychiatry is ongoing. ${ }^{[10]}$ Topics explored include preventive and epidemiological aspects, and methodologies have been developed to conduct focused research. ${ }^{[11,12]}$

\section{Conclusion}

In conclusion, incorporating spirituality in the approach to psychiatric practice and training, especially in a SA context, offers a rich field of exploration and inquiry and has become a legitimate component of the consideration given by mainstream scientific endeavour and evidence-based practice.

\section{References}

1. Pargament KI, Lomax JW. Understanding and addressing religion among people with mental illness. World Psychiatry 2013;12(1):26-32. [http://dx.doi.org/10.1002/wps.20005]

2. Cook C, Powell A, Sims A, eds, Royal College of Psychiatrists. Spirituality and Psychiatry. London: RCPsych Publications, 2009.

3. Janse van Rensburg B, ed. The South African Society of Psychiatrists (SASOP) and SASOP State Employed Special Interest Group (SESIG) Position Statements on Psychiatric Care in the Public SectorS Afr J Psychiatr 2012;18(3):133-148. [http://dx.doi.org/10.7196/SAJP.374]

4. Janse van Rensburg ABR, Poggenpoel M, Myburgh CPH, Szabo CP. Experience and views of academic psychiatrists on the role of spirituality in South African specialist psychiatry. Rev Psiquiatr Clín 2012;39(4):122-129. [http://dx.doi.org/10.1590/S0101-60832012000400002]

5. Bulbulia T, Laher S. Exploring the role of Islam in perceptions of mental illness in a sample of Muslim psychiatrists based in Johannesburg. S Afr J Psychiatr 2013;19(2):52-54. [http://dx.doi. org/10.7196/SAJP.396]

6. Padayachee P, Laher S. South African Hindu psychologists' perceptions of mental illness. J Relig Health 2014;53(2):424-437. [http://dx.doi.org/10.1007/s10943-012-9646-1]

7. Puchalski CM, Larson DB. Developing curricula in spirituality and medicine. Acad Med 1998;73(9):970-974.

8. Janse van Rensburg B, Szabo CP, Myburgh CPH, Poggenpoel M. Competence of medical students and residents in psychiatry regarding spirituality, at a South African school of clinical medicine. Int J Psychiatry Med 2013;45(2):175-188. [http://dx.doi.org/10.2190/PM.45.2.f]

9. Janse van Rensburg ABR, Poggenpoel M, Szabo CP, Myburgh CPH. Referral and collaboration between South African psychiatrists and religious or spiritual advisers: Views from some psychiatrists. S Afr J Psychiatr 2014;20(2):40-45. [http://dx.doi.org/10.7196/SAJP.533]

10. Peteet JR, Lu FG, Narrow WE, eds. Religious and Spiritual Issues in Psychiatric Diagnosis. A Research Agenda for DSM-V. Arlington: American Psychiatric Association, 2011.

11. Hill PC, Dwiwardani C. Measurement at the interface of psychiatry and religion: Issues and existing measures. In: Verhagen J, van Praag H, Lopez-Ibor JJ, Cox JL, Moussaoui D, eds, World Psychiatric Association Religion, Spirituality and Psychiatry Section. Religion and Psychiatry: Beyond Boundaries. Chichester: Wiley-Blackwell, 2010.

12. Koenig, HG. Spirituality and Health Research. Methods, Measurements, Statistics and Resources. West Conshohocken: Templeton Press, 2011.

\section{A B R Janse van Rensburg}

Associate Professor, Department of Psychiatry,

University of the Witwatersrand, Johannesburg, South Africa

albert.jansevanrensburg@wits.ac.za

S Afr J Psych 2014;20(4):131. DOI:10.7196/SAJP.594 